\title{
DIFFERENCES AND SIMILARITIES IN THE NON-VERBAL LANGUAGE OF THE PEOPLES OF THE BLACK SEA REGION AND THE BALKAN PENINSULA
}

\author{
(C) Nazhavat N. Abueva, Atikat Sh. Archilaeva, Yulduz U. Khochavova \\ Dagestan State Technical University, Dagestan State University \\ of National Economy, Makhachkala, Republic of Dagestan, Russian Federation \\ najavat_abueva@mail.ru
}

The last decades have witnessed a growing interest in the contribution of pragmatism and non-verbal semiotics to the study of communication. Pragmatics rooted in philosophy, anthropology, sociology, explores language in social contexts, the ways in which people create and understand meanings through language. This branch of linguistics was developed in the 70s last century. The term pragmatics was invented in the 1930s by philosopher and psychologist C. Morris. According to his theory, signs do not refer to physical signs, but to the tone of voice and body language, i.e. movements, gestures, postures which often accompany speech. The application of semiotic concepts and methods in the field of cultural research today is the production and interpretation of meanings that are created through the deployment of the actions of objects that function as signs. The system of signs is made up of semantic relations that may exist between these signs. Such a relationship unfolds in space and time. The main attention in this work is paid to the consideration of the ways and means of expressing consent and disagreement in the language of the peoples of the countries of the Black Sea basin and the Balkan. A comparative typological study of the symbolic meaning of this expression in the non-verbal language of the people of Bulgaria and neighboring countries under the rule of the Ottoman Empire has been carried out.

Key words: non-verbal semiotics, language, culture, peoples of the Black Sea region.

\section{[Н.Н. Абуева, А.Ш. Арчилаева, Ю.У. Хочавова Различия и сходства в невербальном языке народов Черноморского региона и Балканского полуострова]}

Последние десятилетия стали свидетелями роста интереса к вкладу прагматизма и невербальной семиотики в изучение коммуникации. Прагматика, уходящая корнями в философрию, антропологию, социологию исследует язык в социальных контекстах, способами, которыми люди создают и понимают значения с помощью языка. Это отрасль лингвистики разработана в 70-х гг. прошлого века. Термин прагматика был изобретен в 1930-х гг. фрилософом и психологом Ч. Моррисом. Согласно его теории, знаки относятся не к физическим знакам, а к тону голоса и языку тела - движениям, жестам, позам, которые часто сопровождают речь [6, с. 55-59]. Применение семиотических концепций и методов в сфрере культурных исследований сегодня - это производство и интерпретация значений, которые создается путем развертывания действий объектов, функционирующих как знаки. Систему знаков составляют смысловые отношения, которые могут существовать между этими знаками. Такие отношения развертывается в пространстве и времени. Основное внимание в данной работе уделяется рассмотрению способов и средств выражения согласия и несогласия в языке народов стран черноморского бассейна и Балкан. Проведено сравнительно типологическое изучение символического значение данного выражения в невербальном языке народа Болгарии и соседних стран, находящихся под господством Османской империи.

Ключевые слова: невербальная семиотика, язык, культура, народы Черноморского региона.

Nazhavat N. Abueva - Ph.D. in Philology, Professor, Dagestan State Technical University, Makhachkala, Dagestan Republic, Russian Federation.

Atikat Sh. Archilaeva - Assistant Professor, Dagestan State Technical University, Makhachkala, Dagestan Republic, Russian Federation.

Yulduz U. Khochavova - Ph.D. in Philology, Associate Professor, Dagestan State University of National Economy, Makhachkala, Dagestan Republic, Russian Federation. 
Абуева Нажават Надыровна - кандидат фрилологических наук, профрессор, Дагестанский государственный технический университет, г. Махачкала, Республика Дагестан, Российская Федерация. Арчилаева Атикат Шамильевна - старший преподаватель, Дагестанский государственный технический университет, г. Махачкала, Республика Дагестан, Российская Федерация.

Хочавова Юлдуз Умарпашаевна - кандидат филологических наук, доцент, Дагестанский государственный университет народного хозяйства, г. Махачкала, Республика Дагестан, Российская Федерация.

While different cultures have different symbol systems, one symbol is common to all and it is language. The constant development of language and culture is the permanent development and improvement of society, which has accelerated with the advent of the Internet, which has removed physical barriers and accelerated the exchange of information between people. In the early 20s of the last century, Edward Sapir and Benjamin Lee Whorf wrote that culture is determined by reality, and the interpretation of reality takes place in the language of society with their characteristic features. For example, the number 4 in Pythagoreanism means perfection, harmonious proportion (four seasons, four cardinal directions, etc.), but in Japan, this symbol is considered unlucky, its verbal pronunciation is similar to the Japanese word 死 (death). The Japanese avoid the number 4 and try not to use it. They do not number 4 (四) apartments, floors, ward offices [11, pp. 67-70].

Everyone knows that the language through which communication takes place is a distinguishing feature of humans from primates. However, language is much more than just a means of communication, it is also an integral part of culture. While there is still debate about whether a particular language influences the thought process or whether people's culture actually influences language, there is no doubt that language and culture are closely related.

Non-verbal semiotics are symbolic non-verbal gestures, postures, signals that have all the attributes of the sign system. An environment in which non-verbal behavior, consisting of parts and / or sets of elements, becomes a form of communication, arouses a growing interest in semiotics [1, p. 73].

In the age of globalization, the function of non-verbal communication is increasing. Thus, language proficiency, even perfect one of another culture without the skills of nonverbal behavior associated with this language can lead to intercultural conflict, misunderstanding and ambiguity in communication, despite the fluency of speech. Each culture interprets body language, gestures, posture, voice noises differently $[1$, p. 87] "... non-verbal behavior plays an important role in this in the communication of people, it helps to share emotions, agreements and disagreements, in other words, helps to communicate intentions along with verbal language. On the other hand, non-verbal behavior can also spoil communication when there is a lack of language fluency [1, p. 87].

The origins of the modern theory of semiotics can be traced back to the two main scientists, firstly, the Swiss linguist Ferdinand de Saussure (1857 - 1913), for whom "semiology" was the study of the role of signs as part of social life [1, p. 87] and, secondly, the American linguist Charles Sanders Peirce (1839 - 1914), who calls for a triadic approach of meaning that includes three modes: sense, interpretation, and meaning. The field of research was the "formal" doctrine of signs" [7, p. 274].

Peirce's pragmatism is a method of transforming certain types of signs into clearer signs in order to overcome linguistic or conceptual confusion. To get to the interpretant, it is necessary to determine the "effects" or consequences of the signs or ideas in question [13].

Twentieth-century semioticians Claude Lévi-Strauss, Jacques Lacan, Michel Foucault, Jacques Derrida, Roland Barthes and Julia Kristeva and others applied the princi- 
ples of Peirce and Saussure in various fields, including aesthetics, anthropology, psychoanalysis, communication, semantics, etc. [14].

Since Darwin's fundamental works, the universality of facial expression has remained one of the oldest controversies in the biological and social sciences. In brief, Hypothesis of universality states that all people report six basic internal emotional states (happiness, surprise, fear, disgust, anger and sadness) using the same facial movements due to their biological and evolutionary origin [12, pp. 843-850].

As in the days of Charles Darwin, so in our time, almost everywhere in the world, a nod of the head means "Yes", and shaking the head from side-to-side means "No". A slight nod of the head is used as a greeting, especially when two people greet each other from a distance. It sends a message: "Yes, I recognize you." The speed and frequency with which a person nods when you speak to them can convey different meanings. Nodding slowly means that the person is listening very carefully and deeply interested in what you are saying. A quick nod means the listener is non-verbally telling you, "I've heard enough, let me speak now." Sometimes people quickly nod their heads before interrupting the speaker. After they interrupt, they willingly express their point of view. For example, during a conversation, if a person says, "Sounds good" or "Okay, let's do it," shaking their head from side to side, then it's clear that they don't really mean what they are saying. "The model of the value space of any culture is both verbal and non-verbal communication, and many misunderstandings can be avoided by preparing in advance for a meeting with a particular culture" [1, p. 81].

When non-verbal signs conflict with verbal messages, it is better to believe the nonverbal ones, they are more likely to be true. However, every pattern has an exception. The intelligibility of a symbolic language denotes the meaning embedded in them and depends on the correct interpretation of these symbols. Although the language is symbolic, its symbols are organized in a certain system, and with their own arrangement system. The concept of pragmatic language is equivalent to the concept of social skills, it also applies to the verbal and non-verbal rules that govern social interactions. While these rules vary greatly from culture to culture, they are used every day. In order to identify the cultural characteristics of speech acts and study the existence of linguistic communities, ethnographers "described language codes as a determining factor of the boundaries of ethnic, social and other groups." Since the initial interest in evolutionary theory, the scientific world has considered four deterministic theories that have replaced Social Darwinism. This search for new approaches began before the First World War, when the emphasis shifted from economic theory to geographical, psychological and cultural theory - in approximately this order [8, pp. 88-90].

For example, one of the countries located in the territory in Southeastern Europe, which is now Bulgaria, was the battlefield of the earliest civilizations. The Thracians have lived in what is now known as Bulgaria since about $3500 \mathrm{BC}$ and were incorporated into the Roman Empire in the first century AD. During the decline of the empire, the Goths, Huns, Bulgars and Avars invaded this territory. Bulgars, who crossed the Danube from the north in 679 , took control of the region. Although the country bears the name of the Bulgars, the Bulgar language and culture gave way to the Slavic language, writing and religion. The first Bulgarian state was founded in $681 \mathrm{AD}$ after the unification of the tribes that came from Central Asia with the local Slavic tribes. The introduction of a common religion, language and alphabet united ethnically and culturally different peoples and developed the Bulgarian national identity. In the period $893-1280$, the Bulgars conquered most of the Balkan Peninsula twice, but from 1396 the Ottoman Empire proclaimed Bulgaria a Turkish province. Despite its collapse, the Ottoman Empire was one of the largest, longest and most successful empires in world history. There are many reasons why the empire was so successful, but some of them include its very strong and organized army and its central- 
ized political structure. These first successful governments made the Ottoman Empire one of the most important in history. At its peak, the Ottoman Empire included the territories of Turkey, Greece, Bulgaria, Romania, Macedonia, Hungary, Israel, Jordan, Lebanon, Syria, Egypt, as well as parts of the Arabian Peninsula and North Africa. The influence of the Ottoman Empire in Bulgaria lasted until 1878, until the victory of Russia in the RussianTurkish war (1877-1878) [5, p. 96], [9, p. 45-52].

When considering how and why some of the Bulgarian customs originated, it is important to understand the duration of the Ottoman rule, both in Bulgaria and in other Balkan countries. Nowadays, according to the CIA World Factbook, the Bulgarian ethnic group of the country makes up almost $85 \%$ of the country's population, slightly less than $10 \%$ of Turks and less than $5 \%$ of Romani. The rest is made up of about 40 minority groups (Greeks, Russians, Ukrainians, etc.) [16].

The Ottoman era has left its mark on everyday customs and gestures, which are of great importance in the cultural codes of the inhabitants of the Balkan Peninsula. Along with the abundance of Turkisms in speech, non-verbal discourse is marked by characteristic "post-Ottoman" signs: harsh gestures, sometimes spitting to show disappointment or indignation, etc. [10, pp. 65-70].

Today in Bulgaria about $60 \%$ of the working-age population (from 25 to 64 years old) speak at least one foreign language, most of the older Bulgarians understand and speak fluent Russian. English is widely used as it is taught in all schools and about two thirds of students study English or German at universities. Outside Sofia, translators are often required for business meetings. Other languages are widely used, such as Spanish and French, Bulgarians also understand other Slavic languages when they are spoken slowly, such as Serbian and Macedonian.

The Sapir-Whorf hypothesis is based on the idea that people perceive their world through their language and therefore they understand their world through the culture embedded in their language. The hypothesis, which is also called linguistic relativity, claims that language forms thinking [3, pp. 169-182].

Non-verbal communication can help or prevents from the conversation as easily as words can. Difficulties can arise due to a lack of understanding of the specific body language of a particular people. Knowledge of the non-verbal signs of the language will help to avoid unintentional offenses. Consider an example of head nodding. There are various theories as to why the nod is so often used to indicate agreement and acceptance of the other person's thoughts. A simple assumption is that this is a form of social bow, indicates that a person is ready to accept what another person says or asks [4, pp. 275-276].

In most Western cultures, moving the head up and down is understood as an expression of agreement, while moving the head from side to side expresses disagreement. However, this non-verbal communication is not universal. Despite the globalization and glocalization processes in the modern world, a nod of the head is not always unambiguous to the meaning of "yes". Exceptions in the interpretation of the nod take place in countries such as Bulgaria, Turkey, Greece, Iran, Albania, Macedonia, partly the region of Italy: the regions of the Neapolitan Riviera and Sicily, which follow different methods of non-verbal communication [2, p. 15-19].

To say yes, Turks often simply close their eyes, carefully raising and lowering their heads. To say "no" they also quickly raise their head and eyebrows up, but at the same time click their tongue in the teeth, which is more like "yes".

In Greece, neighboring Bulgaria, to say "yes" and "no" Greeks do not nod or shake their heads in different directions. The non-verbal "yes" is reminiscent of the American "no" gesture. The Greek "yes" is a tilt of the head to both sides, movement to the sides, with slightly closed eyes. This is very similar to the gesture that Americans make when they don't understand something. Oddly enough, "yes" in Greek naí verbally sounds "nai", a 
sound similar to the English "no." Confusion is guaranteed. Likewise, the Greek "no" is more like the American yes. When they want to say no, the Greeks raise their eyebrows and their entire head up, softly clicking their tongue, which is like one nod.

Albanians also nod when they mean "no" and shake their heads when they mean "yes". In Eastern Macedonia, closer to the border with Bulgaria, there is a similar nonverbal custom: shaking your head can mean "yes", while nodding your head can mean "no" [17].

Whatever the background, the custom in countries that have marked their independence from the Ottoman Empire to nod "no" and shake your head from side to side in response to "yes" persists in our time. However, most Bulgarians in particular know that their customs differ from those of many other cultures. If a Bulgarian knows that he is talking to a foreigner, he can help the visitor by changing this movement. In fact, people tend to change their behavior to fit the current social situation. A person's behavior also changes if a person is in a new situation or if a person is not sure, if he does not know how to behave, and he will receive signs and signals from other people.

The main object of the study of the semiotics of culture is the hierarchy of sign systems of culture, both existing and historical. The correlations between these sign systems transform it into the semiotics of the history of culture. The object of "the study of the semiotics of culture is not only the hierarchy of the sign systems of culture, but also the existing and historical relationships between these sign systems." On the one hand, the semiotics of culture is able to conduct a deeper study of texts as intermediaries between reality and cultural tradition, on the other hand, semiotics of culture as a semiotics of the history of culture can be "methodologically used to create a new (chronotopic) theory of culture." Conceptualization of the object of study of the semiotics of culture into a hierarchy of sign systems of culture and existing ones, as well as "the historical relationship between these sign systems turns the latter into a semiotics of the history of culture." The development of semiotics of the history of culture of the Bulgarian people in this work is considered from the standpoint of semiotics of culture as the history of culture which can be further used for the chronopotic theory of culture of other countries of the Balkan Peninsula [15].

\section{Лumepamypa}

1. Петрова Ю.А. Язык как модель ценностного пространства культуры, Монография. Издательство: № 129/3465, Ростовский государственный экономический университет (РИНХ). 2019. С. 98. [Электронный ресурс].

URL: https://www.researchgate.net/profile/Yulia_Petrova.

2. Петрова Ю.А., Шевкун Ю.С. Мифы и легенды Черноморского региона // Научный альманах стран Причерноморья. 2019. № 1 (17). С. 15-19.

3. Уорф Б.Л. Наука и языкознание // Новое в лингвистике. М.: Иностранная литература, 1960. Вып. 1. с.169-182.

4. Darwin Ch. Expression of Emotion in Man and Animals D. Appleton \& Company, pp. 275-276, 1913, p. 372.

5. Glénard A. Русско-турецкая война 1877 года: историко-дипломатическій этюд. Tip. V.TA. Barbel̆, c.96, 1878. C. 407.

6. Morris Ch. Signs, Language and Behavior. Paperback, Literary Licensing, LLC, pp.55-59. 2011. p.380.

7. Peirce, Ch.S. Collected Papers of C. S. Peirce, Volumes I and II: Principles of Philosophy and Elements of Logic, ed. by C. Hartshorne, P. Weiss, Belknap Press, p.274, 1932. 962 p.

8. Petrova Y.A. Ethnography of communication, Гуманитарные и социальноэкономические науки. 2016. № 2 (87). с. 88-90. 
9. Petrova $Y u$., Bukreyeva $V$. Culture of the peoples of the Balkan peninsula: history and modern influence of Turkey, Научный альманах стран Причерноморья, 2020. № 3 (23). C. 45-52.

10. Petrova Yu., Kuleshova K. Cultural and historical evolution of the Turkish language under the influence and borrowing of European languages, Научный альманах стран Причерноморья. 2020. № 1 (21). С. 65-70.

11.Petrova Yu.A., Alehina M.V., Romanchenko A.P., Shkrobot V.Y. Hikikomori as psychological type of person by the example of Japan, Problems of development of a personality: diversity of approaches. Materials of the IV international scientific conference, Vedecko vydavatelske centrum Sociosfera-CZ s.r.o. (Прага), 2017. C. 67-70.

12. Susskind J.M., Lee D.H., Cusi A., Feiman R., Grabski W. \& Anderson A.K. Expressing fear enhances sensory acquisition, Nature Neuroscience, 2008. pp.843-850.

13. Thayer H.S., Rosenthal S.B. Pragmatism, Encyclopædia Britannica, 2020. URL: https://www.britannica.com/topic/pragmatism-philosophy

14. The Editors of Encyclopaedia Britannica. Semiotics. Encyclopædia Britannica, May 21, 2020. URL: https://www.britannica.com/science/semiotics.

15. Torop P. Semiotics of cultural history. Sign Systems Studies. 45.317. 10.12697/SSS. 2017. 45.3-4.07.

16.World Population Review. 2020 World population by country. URL: https://worldpopulationreview.com.

\section{References}

1. Petrova Yu.A. Yazyk kak model tsennostnogo prostranstva kultury, Monografiya. Izdatelstvo: No.129/3465, Rostovskiy gosudarstvennyy ekonomicheskiy universitet (RINKH) [Language as a model of the value space of culture, Monograph. Publisher: No. 129/3465, Rostov State University of Economics (RINH)]. 2019. 98 p. Available at: https://www.researchgate.net/profile/Yulia_Petrova (accessed 15 January 2021) (In Russian).

2. Petrova Yu.A., Shevkun Yu.S. Mify i legendy Chernomorskogo regiona [Myths and legends of the Black Sea region]. Nauchnyy almanakh stran Prichernomorya. 2019. No. 1 (17). pp. 15-19.

3. Whorf B.L. Nauka i yazykoznaniye [Science and linguistics]. Novoye $v$ lingvistike. Moscow: Inostrannaya literatura, 1960. V. 1. pp.169-182. (In Russian).

4. Darwin Ch. Expression of Emotion in Man and Animals D. Appleton \& Company, pp. 275-276, 1913, 372 p.

5. Glénard A. Russko-turetskaya voyna 1877 goda: istoriko-diplomaticheskíy etyud [Russian-Turkish War of 1877: Historical and Diplomatic Study]. Tip. V.TA. Barber. 1878. 407 p. (In Russian).

6. Morris Ch. Signs, Language and Behavior. Paperback, Literary Licensing, LLC. 2011. $380 \mathrm{p}$.

7. Peirce Ch.S. Collected Papers of C. S. Peirce, V. I and II: Principles of Philosophy and Elements of Logic, ed. by C. Hartshorne, P. Weiss, Belknap Press. 1932. 962 p.

8. Petrova Y.A. Ethnography of communication. The humanities and social-economic sciences. 2016. No. 2 (87). pp. 88-90. 
9. Petrova Yu., Bukreyeva $V$. Culture of the peoples of the Balkan peninsula: history and modern influence of Turkey. Science Almanac of Black Sea Region Countries. 2020. No. 3 (23). pp. 45-52.

10. Petrova Yu., Kuleshova K. Cultural and historical evolution of the Turkish language under the influence and borrowing of European languages. Science Almanac of Black Sea Region Countries. 2020. No. 1 (21). pp. 65-70.

11. Petrova Yu.A., Alehina M.V., Romanchenko A.P., Shkrobot V.Y. Hikikomori as psychological type of person by the example of Japan. Problems of development of a personality: diversity of approaches. Materials of the IV international scientific conference, Vedecko vydavatelske centrum Sociosfera-CZ s.r.o. (Prague), 2017. pp. 67-70.

12. Susskind J.M., Lee D.H., Cusi A., Feiman R., Grabski W. \& Anderson A.K. Expressing fear enhances sensory acquisition. Nature Neuroscience. 2008. pp.843-850.

13. Thayer H.S., Rosenthal S.B. Pragmatism. Encyclopædia Britannica. 2020. Available at: https://www.britannica.com/topic/pragmatism-philosophy (accessed 15 January 2021).

14. The Editors of Encyclopaedia Britannica. Semiotics. Encyclopædia Britannica, May 21, 2020. Available at: https://www.britannica.com/science/semiotics (accessed 15 January 2021).

15. Torop P. Semiotics of cultural history. Sign Systems Studies. 45. 317. 10.12697/SSS. 2017. 45.3-4.07.

16. World Population Review. 2020 World population by country. Available at: https://worldpopulationreview.com. (accessed 15 January 2021). 